\section{Elżbieta Tabakowska}

prof. emer. Uniwersytetu Jagiellońskiego

w Krakowie

elzbieta.muskat-tabakowska@uj.edu.pl
Data przesłania tekstu do redakcji: 19.07.2016

Data przyjęcia tekstu do druku: 07.11.2016

\title{
Co, jak i po co, czyli o związkach formy z funkcją na przykładzie haiku
}

\author{
Let chaos storm! \\ Let cloud shapes swarm! \\ I wait for form. \\ (Robert Frost)
}

\begin{abstract}
Tabakowska Elżbieta, Co, jak i po co, czyli o zwiąkach formy z funkcja na przykładzie haiku (What, How and What for - on the Relation Between Form and Function as Illustrated by Haiku). "Poznańskie Studia Slawistyczne" 13. Poznań 2017. Publishing House of the Poznań Society for the Advancement of the Arts and Sciences, pp. 151-164. ISSN 2084-3011.

The paper addresses the problem of mutual relation between form and function as exemplified by haiku. Focusing upon the structure of haiku conducive to epiphany, it discusses some general aspects, independent of the differences between Eastern and Western varieties of the form. The "literariness" of the genre is demonstrated with reference to dimensions of imagery (as defined in Langacker's model of cognitive grammar), and to the strongly metonymic character of haiku. Finally, some shortcomings of "Polish haiku" are shown as a function of its culture-bound untranslatability.
\end{abstract}

KEYwORDs: dimensions of imagery; epiphany; figure; "haiku moment"; kigo; kire-ji; literariness; objectification; transcreation

\section{Wstęp}

Ogłaszając zamiar wydania tematycznego numeru „Poznańskich Studiów Slawistycznych”, redaktorzy pisma proszą o prace powstałe w wyniku „refleksji nad złożonymi powiązaniami formy i funkcji”. Jako przedmiot rozważań wskazują potencjalnym autorom teksty kultury, z uwzględnieniem praktyki (a zapewne także teorii) przekładu literackiego, który w tej kategorii zajmuje oczywiście poczesne miejsce. Przekład oznacza bowiem konieczność przeniesienia nie tylko treści, ale także powiązań między 
treścią i formą oryginalnego utworu i jego funkcji w odmienny kontekst kulturowy oraz - jak czytamy w przywoływanym call for papers - wynikające z tej konieczności „wyzwania, trudności, rozstrzygnięcia”.

Relacja między formą i funkcją ma zazwyczaj określony kierunek: zamierzona funkcja obiektu, na przykład tekstu kultury, narzuca wybór jego formy, czyli - przypominając dewizę amerykańskiego architekta Louisa Sullivana cytowaną w call for papers redakcji „PSS” - można by przyjąć, że forma zawsze podąża za funkcją (form ever follows function). W tekstach określanych jako „literackie” relacja ta może jednak przybierać także kierunek odwrotny: ugruntowana w danej kulturze forma narzuca wówczas odbiorcy określoną funkcję utworu. W efekcie powstaje i rozwija się zespół norm, których przekraczanie i modyfikacja stanowią prerogatywę artystów. Właśnie ta dwukierunkowość relacji między formą i funkcją jest istotnym elementem rozważań przedstawionych w poniższym szkicu.

Jako ilustrację i przedmiot analizy wybrałam haiku - gatunek poetycki silnie uwarunkowany wymogami formalnymi, a równocześnie podlegający licznym adaptacjom i transformacjom. Teoretycy literatury poświęcili $\mathrm{mu}$ - i nadal poświęcają - ogrom prac, oferując interpretacje i analizy, odnosząc haiku do kulturowych i literackich tradycji Dalekiego Wschodu i Zachodu, pokazując kierunki jego ewolucji w czasie i w przestrzeni. Poniższy szkic przyjmuje wąską perspektywę językoznawcy, patrzącego na tekst „tu i teraz” - wprawdzie w pozajęzykowym kontekście, ale przede wszystkim w aspekcie struktury. Musi więc - z konieczności - być fragmentaryczny i zawierać duże uproszczenia; powstał jednak w nadziei, że owa odmienna perspektywa okaże się dla czytelnika interesująca.

\section{Haiku: forma, treść, funkcja}

Haiku jest, jak wiadomo, jednym ze specyficznych gatunków należących do literackiej kultury Japonii. Ma za sobą ponad czterechsetletnią tradycję, a za jego twórcę uważa się siedemnastowiecznego poetę Matsuo Bashō. Znalazł on w ojczyźnie i poza jej granicami licznych naśladowców, których nie brak także dziś, a klasyczne haiku ulegało na przestrzeni wieków licznym modyfikacjom. Gatunek uprawia obecnie wielu twórców, od doświadczonych artystów po młodych adeptów poezji i amatorów. Same wiersze, a także ich opracowania i omówienia gatunku, publikuje wiele 
wydawnictw na świecie; powstają poświęcone im specjalistyczne pisma, odbywają się międzynarodowe konferencje, organizowane są konkursy i turnieje. Zainteresowany czytelnik bez trudu znajdzie obszerną literaturę przedmiotu. Gatunek haiku - lub ,haiku”, jak chcą niektórzy polscy badacze (cf. np. Śniecikowska, 2009, 147) - pojawił się oczywiście także w Polsce; liczne przekłady (Miłosz, Żuławska-Umeda, Kowalska) stały się inspiracją dla oryginalnej twórczości poetów i pisarzy (Miłosz, Engelking, Jaworski, Tchórzewski, Stańczyk, Lisowski, Pasierb i inni) ${ }^{1}$.

Teoretycy omawiają związki haiku z myślą filozoficzną i religiami Wschodu - filozofią zen, buddyzmem, taoizmem czy animizmem (cf. Kowalska, 2002). Nie one jednak stanowią główny przedmiot niniejszych rozważań, a streszczanie wybranych choćby opracowań oznaczałoby wykraczanie poza kompetencje autorki oraz zarysowane w tym miejscu ramy. Istotne wydaje się natomiast określenie, czym jest „literackość”, wyróżnik tekstów uznawany powszechnie za cechę stanowiącą podstawę, a zarazem uzasadnienie ścisłych powiązań między formą, treścią i funkcją.

Literaturze przypisuje się na ogół określone wyznaczniki formalne oraz specyficzne funkcje. Opinie literaturoznawców obejmują szerokie spektrum postaw: od tezy, że ,język literacki” jest szczególną odmianą języka ogólnego z własnym odmiennym zasobem słów i struktur gramatycznych, po przeświadczenie, że między językiem „literackim” i „nieliterackim” nie ma istotnych różnic jakościowych, a „literackość” tekstu jest jedynie skutkiem realizacji zamiaru twórcy i określonej postawy odbiorcy. W tym drugim ujęciu literackość tekstu jest funkcją kontekstu, w jakim dany tekst powstaje, a następnie staje się przedmiotem czytelniczego odbioru ${ }^{2}$. Innymi słowy, wyznacznikiem literackości tekstu jest jego - zamierzona przez twórcę i odtworzona (w jakiejś mierze) przez odbiorcę - funkcja, realizuje się ona jednak przez rozpoznanie formy, z którą jest zespolona.

Poniżej chciałabym uzasadnić tezę, że o „literackości” haiku przesądza fakt, iż jego racją bytu jest prymat funkcji poetyckiej, tak jak ją zdefiniował Roman Jakobson (1960): „language form is important in its own right” (za: Jarniewicz, 2015, 228). Innymi słowy, forma językowa wiersza stanowi jego dominantę.

\footnotetext{
${ }^{1}$ Szerszą bibliografię ,,polskich haiku” znaleźć można w: Śniecikowska, 2009; 2015.

${ }^{2}$ Taką właśnie definicję proponuje wybitny teoretyk literatury, Edward Balcerzan (2013).
} 


\subsection{Haiku: co?}

Treści przedstawiane w (tradycyjnym) haiku są określone równie ściśle jak wymogi czysto formalne. Pierwszym - i najważniejszym - wymogiem jest unikanie tematów, które budzą żywe emocje: autor haiku przedstawia obraz, ale powstrzymuje się od oceny tego, co widzi. Wiersz pozbawiony jest zatem „subiektywnej interpretacji świata” (Śniecikowska, 2009, 150), a obserwujący podmiot stapia się z obserwowanym przedmiotem; to „zespolenie podmiotu z przedmiotem" (Śniecikowska, 2009, 131) odpowiada na gruncie językoznawstwa kognitywnego Langackerowskiej obiektyfikacji (Langacker, 2005). Oznacza (sprzeczne z egotyzmem czy ekshibicjonizmem charakterystycznym dla nie-orientalnej poezji lirycznej) wyzbycie się ,ja” i przesunięcie podmiotu lirycznego na dalszy plan.

Właściwym przedmiotem wiersza jest natura świata i człowieka, więc to właśnie ona staje się pierwszoplanową figurą na płaszczyźnie konceptualizacji, która zostaje wyprofilowana w językowej strukturze tekstu. Jest to zatem figura w znaczeniu, jakie nadaje temu terminowi Langacker, omawiając pojęciowe aspekty konstrukcji sceny i obrazowania (Langacker, 2009, 85-130). Ponieważ pierwszy z dwóch obrazów zawartych w tradycyjnym haiku przedstawia konkretne doświadczenie, z reguły związane z porą roku i przyrodą, często pojawiają się realia kulturowe, których znajomość jest warunkiem zrozumienia wiersza. Teresa Kowalska (2002) przytacza tu jako przykład klasyczne haiku Bashō ${ }^{3}$ :

ze wszystkich stron

lecą płatki wiśni

wiatrem gnane do jeziora $\mathrm{Nio}^{4}$.

Nio jest wielkim jeziorem i przeciwstawienie jego ogromu maleńkim płatkom wiśni „użycza tym ostatnim jakiejś szczególnej czy wręcz

${ }^{3}$ Zachowując pełną świadomość ograniczeń płynących z omawiania angielskich lub polskich wersji japońskich oryginałów, mam nadzieje, że przytaczane teksty w miarę trafnie ilustrują poruszane w tym miejscu ogólne zagadnienia.

${ }^{4}$ Autorka przytacza to haiku we własnym przekładzie, który nazywa „wtórnym”, ponieważ został dokonany na podstawie filologicznego przekładu oryginału na język angielski. Zgodnie z zachodnią tradycją stosuje pisownię pozbawioną wielkich liter i znaków interpunkcyjnych. 
magicznej mocy" (Kowalska, 2002), zwłaszcza w kontekście roli, którą te kwiaty odgrywają w Kraju Kwitnącej Wiśni. Językoznawca spojrzy jednak z uwagą na szczegółowość jako na Langackerowski wymiar obrazowania: „płatki” oznaczają oglądanie kwiatów wiśni z bliska, a więc oddają charakter pierwszego obrazu lepiej niż „kwiaty” właśnie, które byłyby bardziej oczywistym elementem związku frazeologicznego „kwiaty wiśni”. Odejście od tej zwykłości to nieuchwytna, lecz wyczuwalna „literackość”. Natomiast system polskich czasów gramatycznych nie pozwala orzec, czy płatki lecą właśnie w „chwili haiku”, w której obserwuje je poeta, czy też dzieje się to zazwyczaj, zawsze.

\subsection{Haiku: jak?}

Pierwszą, podstawową cechą formalną gatunku jest jego skrajna lakoniczność, czyli zawarcie maksimum znaczenia w minimalnej ilości językowej materii. Ilość ta jest jak wiadomo precyzyjnie określona: klasyczne haiku jest poetycką miniaturą złożoną z trzech wersów, liczących odpowiednio 5, 7 i 5 sylab. Kształt wizualny i dźwiękowy całości wspomaga warstwę treściową, wykorzystując zasady ikoniczności, które ze względu na zakres niniejszego eseju muszą jednak zostać pominięte (cf. np. Hiraga, 2003, 331).

Z punktu widzenia językoznawcy istotne są pewne dalsze cechy tradycyjnego haiku. Musi ono zawierać jedno - i tylko jedno - „,cięcie” (kire-ji), czyli realizowaną za pomocą określonego leksemu cezurę między dwoma przeciwstawnymi obrazami składającymi się na treść. Obecność kire-ji jest kompozycyjnym warunkiem powstania haiku w tradycyjnej formie, wzmacnia efekt zestawienia dwóch obrazów, a jednocześnie przełamuje kadencję wiersza, przydając mu dynamiki. W odbiorze natomiast narzuca czytelnikowi krótką pauzę, która zdaniem badaczy gatunku jest momentem potrzebnym na refleksję nad przesłaniem wiersza (Hiraga, 2003, 324).

Ostatnią istotną w tym miejscu obowiązkową cechą klasycznego haiku jest obecność „słowa pory roku” (kigo), które (na ogół w pierwszym wersie) wprowadza obraz, ,żywo odczuwanej chwili” (Polski Portal Literacki) konkretnego wydarzenia, jednostkowego doświadczenia, przeżycia „tu i teraz”, zwanego „chwilą haiku”. Według japońskich poetów 
uprawiających ten gatunek „chwila haiku” jest estetycznym momentem, w którym „słowa oddające przeżycie i samo przeżycie stają się jednym” (Gurga, 2003, 1-3). Innymi słowy, w „chwili haiku” forma zostaje zespolona $\mathrm{z}$ treścią, staje się tą treścią. Zestawienie dwóch obrazów ukazuje prawdziwszą, głębszą rzeczywistość, która często umyka naszej uwadze, ponieważ kryje się w pozornie nieistotnych drobnych fragmentach otaczającego świata. Jest to epifania, określana japońskim słowem satori.

Warto w tym miejscu, niejako na marginesie, zauważyć, że taka precyzyjna struktura, określana jako „dwoistość obrazu” (binary treatment of images, Miller, 2016, 31), w aspekcie analizy czysto językoznawczej doskonale wpisuje się w kognitywistyczną teorię integracji pojęciowej takie próby istotnie były już podejmowane; do najwnikliwszych należą analizy prezentowane w pracach Masako Hiragi (1999, 2003).

\subsection{Haiku: po co?}

Jaką funkcję ma spełniać tradycyjne haiku? Ze względu na formalną lakoniczność, jego zadaniem jest pokierować interpretacją, którą narzuca forma w połączeniu z kontekstem kulturowym. Inherentną cechą języka, a zatem również tworzonych w języku tekstów, jest metonimiczność, którą Ingarden określał mianem miejsc niedookreślenia. Językoznawcy kognitywni (cf. np. Langacker, 2009, 103-104) analizują ją na poziomie zarówno leksyki, jak i struktur gramatycznych, wskazując sposoby uzupełniania wszechobecnych synekdoch, co zapewnia skuteczną komunikację. Lapidarność haiku, odwrotnie, oferuje wiele możliwych „dopełnień”, a odstępstwo od jednoznacznej komunikatywności jest kolejną cechą jego „literackości”. Specyfiką gatunku staje się zatem interakcyjność, co zresztą podkreślają badacze (cf. np. Śniecikowska, 2009; 2012; 2015). Haiku ma ,wywołać poczucie piękna i przyjemności, a nie dokonywać rozbioru i analizy” (Miller, 2016, 37 [przeł. - E.T.]), ma zatem pozwolić czytelnikowi doświadczyć wspomnianej epifanii.

Aby haiku mogło tę funkcję spełnić, czytelnik musi dopełnić treść zgodnie z zasadami, którymi rządzi się gatunek. Jako przykład może posłużyć najbardziej znane haiku Matsuo Bashō, które doczekało się niemal sześciuset przekładów na różne języki i niezliczonych opracowań, tzw. Frog Poem: 
furuike ya kawazu tobikomu mizu no oto

old-pond: frog jumps-in water's sound

[stary-staw: żaba skacze-w wody dźwięk].

Zaznaczone w oryginalnej wersji „cięcie” (wyraz ya) buduje implikowany kontrast między obrazem starego stawu - spokojnego i nieruchomego - a dynamiką skoku żaby (słowa ,pory roku”, symbolizującego wiosnę) i odgłosem budzącego się życia ${ }^{5}$. Metonimiczność klasycznej wersji „haiku o żabie" w angielskim przekładzie badacz gatunku, japoński teoretyk literatury Hasegawa Kai, proponuje „dopełnić” w następujący sposób:

(when) the frog jumped in

(I heard) the sound of water ...(that made me remember, I was sitting by)

the old pond ${ }^{6}$

(kiedy) żaba wskoczyła

(ustyszatem) odgłos wody...

(który sprawil, że sobie przypomniatem jak siedziałem nad) stary $(\mathrm{m}) \operatorname{staw}(\mathrm{em})$.

Interakcyjne otwarcie tekstu powoduje, że liczba wariantów interpretacyjnych staje się niemal nieograniczona. I w tym właśnie sensie „mniej” jest „ciekawiej”, a nie, jak chce kolejny amerykański architekt cytowany w kurendzie „PSS”, Robert Venturi, less is a bore. Jednym z celniejszych polskich tłumaczeń „haiku o żabie” jest w moim przekonaniu wersja Andrzeja J. Nowaka:

stary staw

żaba wskakuje

plusk wody (Izutsu, 2001, 196).

\section{Haiku polskie}

W epoce Internetu, w której powstał specjalny program komputerowy służący do pisania haiku (choć to jednak człowiek musi zadać komputerowi trzy słowa klucze ${ }^{7}$ ), gatunek znalazł oczywiście licznych entuzjastów -

\footnotetext{
${ }^{5} \mathrm{http}$ //haikutopics.blogspot.com/2006/06/kireji.html. 19.07.2016.

${ }^{6} \mathrm{http}$ //haikutopics.blogspot.com/2006/06/sound-of-water.html. 19.07.2016.

${ }^{7}$ https://pl.wikipedia.org/wiki/Haiku. 19.07.2016.
} 
także wśród polskich autorów. Wiersz złożony z 17 sylab w układzie 5-75 okazuje się łatwiejszy do napisania w języku polskim w porównaniu, na przykład, z angielskim, w którym przewaga słów monosylabicznych skłania do rozmaitych odstępstw od tradycyjnej reguły (na ogół w myśl przywoływanej przez redakcję „PSS” zasady Ludwiga Miesa van der Rohe'a less is more...).

Lista autorów - ,zawodowych” poetów i urzeczonych orientalną formą amatorów, twórców z górnych i z niższych półek - jest długa i stale rośnie. Nie podzielając przekonania komentatorów, którzy „wysyp” polskich haiku skłonni byliby uznać za przejaw „doganiania przeoczonej mody” (Michałowski, 1999, za: Śniecikowska, 2015, 140-141), dostrzegam oczywiste niedostatki tej twórczości. Przekonanie, że każdy wiersz napisany w formacie 5-7-5 sylab zasługuje na miano haiku skłania znawców gatunku do wprowadzenia podkategorii oznaczonej cudzysłowem: „haiku”; Śniecikowska mówi w tym kontekście o „«najprawdziwszych» polskich haiku” (2015). Mówiąc przenośnie, nie wystarczy wlać do japońskiego naczynia polskiej zawartości. Tymczasem w przypadku wielu polskich „haiku” budowanych według klasycznych reguł formalnych jest tak, jak pisał amerykański architekt i historyk sztuki Philip Johnson: form follows form, not function: forma podąża za formą, a nie za funkcją. Innymi słowy, większość polskich haiku nie spełnia funkcji analogicznej do tej, którą pełnią haiku pisane po japońsku i osadzone w japońskiej kulturze; są one zatem swoistym ,przekładaniem formy”.

Szczegółowy wykaz cech ,polskich haiku”, których autorzy nie sprostali wymogom ,rezygnacji z tego, co zakorzenione w kulturze europejskiej” lub pozorną prostotę klasycznego pierwowzoru uznali za drogowskaz, zawiera kompetentna i przejrzysta analiza Śniecikowskiej (2012, 142 i n.; 2015). Nie ma zatem potrzeby wyliczania ich w tym miejscu. Ograniczymy się do jednego tylko cytowanego przez badaczkę przykładu:

W pustej szafie

Nagi wieszak

Czeka na spodnie (G. Stańczyk, za: Śniecikowska 2015, 149).

Drobne odstępstwo od liczby sylab (5-7-6) wydaje się mniej istotne niż fakt, że ta ,prościutka migawka z codzienności” jest, jak pisze Śniecikowska, „fascynującym banalizmem” $(2015,149)$, a więc nie ma w niej 
„chwili haiku” i nie wywołuje epifanii - ani w tym sensie, w jakim ją rozumieli dawni japońscy mistrzowie, ani też „nowoczesnej epifanii”, obecnej w literackiej kulturze Zachodu.

\section{Haiku w przekładzie}

Jak sygnalizowałam wyżej, przekłady haiku na inne języki, a w szczególności na język polski, wiążą się z takimi samymi problemami, jakie stają przed autorami oryginalnych ,najprawdziwszych” polskich haiku. O ile - w przypadku utworów wzorowanych na tradycyjnych - zachowanie liczby wersów i sylab jest stosunkowo proste, o tyle konwencje dotyczące funkcji struktury stwarzają problemy trudne do przezwyciężenia. Najtrudniejsze okazuje się oczywiście znalezienie ekwiwalentu kire-ji „cięcia”, niezbędnego środka, który pozwala spełnić utworowi jego zasadniczą funkcję, czyli skłonić czytelnika do twórczej refleksji. Trudność tę dostrzegają zresztą także autorzy przekładów na język angielski, którzy proponują zastąpić „nieprzekładalny rozdzielacz” (untranslatable divi$d e r^{8}$ ) wprowadzaniem znaków interpunkcyjnych - dwukropka, myślnika, trzykropka czy nawet wykrzyknika - jednocześnie w pełni zdając sobie sprawę z niedoskonałości takiego rozwiązania. Oto przykład, dwa różne angielskie przekłady ,haiku o żabie”:

an old pond...

a frog jumps in,

the sound of water

([jakiś] stary staw...

[jakaś] żaba wskakuje,

odgłos wody)

old pond... a frog leaps in

water's sound ${ }^{9}$

([jakiś] stary staw...

[jakaś] żaba wskakuje

wody odgłos).

${ }^{8}$ Termin używany w klasycznej pracy Makoto Ueda, Modern Japanese Haiku, https:// haikutopics.blogspot.com/2006/06/kireji.html. 2.11.2016.

${ }^{9}$ Przeł. W.J. Higginson, http://haikutopics.blogspot.com/2006/06/kireji.html. 19.07.2016. 
O wiele poważniejszym problemem okazuje się konieczność przeniesienia przekładu w całkowicie odmienny kontekst kulturowy. Jak już powiedzieliśmy, haiku jest niezwykle mocno osadzone w japońskiej kulturze, a jego restrykcyjna forma przywołuje skojarzenia niezbędne dla pełnego odbioru. W przypadku cytowanego wyżej klasycznego „haiku o żabie” są to właściwe tej kulturze wartości filozofii zen: „wielka pasja życia, pragnienie maksymalnego wykorzystania każdej przeżywanej chwili, dostrzeganie tych wartości nawet w elementach przyrody, poczucie, że nic, co się zdarza, nie zdarza się w odosobnieniu od innych zdarzeń, że nic nie jest nieważne; współodczuwanie, wyostrzona świadomość wszelkich współzależności, włączając wzajemne zależności między ludzkimi zmysłami”" (Henderson, 1958, 21, cyt. za: Jarniewicz, 2016, 231 [przeł. E.T.]).

Spójrzmy na przekład „haiku o żabie” pióra Czesława Miłosza:

Stara sadzawka,

Żaba - skok -

Plusk $^{10}$.

Renata Mitsui (2016) ocenia to thumaczenie jako „niewątpliwie nieudane", nie podając jednak powodów. Wydają się one jednak dość oczywiste: aż trzy próby kire-ji tną tekst na kawałki, tworząc trzy migawkowe obrazy zakończone efektem dźwiękowym. Nie ma w tym wierszu ani „chwili haiku”, ani inspirowanej formą epifanii. Innymi słowy, forma nie spełnia swojej funkcji. Na uwagę zasługuje także zapis graficzny: wersy rozpoczynają się od wielkich liter (próba oddania „cięć”?), a poeta nadał im kształt odwróconej piramidy. Gdyby w interpretacji zastosować zasadę ikoniczności obrazowej, można by uznać, że każdy z trzech obrazków jest mniej ważny niż poprzedni. Dlaczego miałoby tak być?

Nieprzekładalność haiku nie jest typem nieprzekładalności, na którym zazwyczaj skupiają się krytycy przekładu. Nie chodzi o elementy leksykalne oddające realia kulturowe (jak wiadomo, nikt, kto nie spróbował bigosu,

${ }^{10}$ Miłosz, 1992. Cyt. wg. https://www.wykop.pl/wpis/22381687/stara-sadzawka-zabaskok-plusk-to-jest-slnny-wiers/. 21.07.2016. Wypada zauważyć, że jest to thumaczenie pośrednie, z języka angielskiego. Rozważania na temat takiego przekładu - zakazanego surowo przez większość teoretyków przekładu - otwierają obszar rozważań, które wykraczałyby poza ramy niniejszego eseju. 
nie będzie wiedział, jakie jest prawdziwe znaczenie tego słowa). Problemem jest literacka tradycja i szeroki kontekst kulturowy, w którym haiku jest silnie zakorzenione, ale także - a może przede wszystkim - szeroka (i głęboka) „wiedza tła”, którą przywołuje konwencjonalna forma. Nieprzekładalność haiku jest wynikiem konfrontacji dwóch odległych kultur, dlatego jest to wdzięczny przedmiot analiz prowadzonych w duchu ,zwrotu kulturowego", jaki nastąpił we współczesnym przekładoznawstwie.

\section{Transcreation?}

Powyższe rozważania prowadzą do następującego pytania: skoro przyczyna nieprzekładalności haiku leży w nieprzystawalności tradycji i kultur, to może należałoby ich tłumaczenie - translation - zastąpić procesem transcreation, który, choć jeszcze ostatecznie nienazwany po polsku ${ }^{11}$ powoli zyskuje sobie prawo obywatelstwa we współczesnej translatologii?

Pojęcie transcreation - czyli przeniesienia przekazu na nowy grunt kulturowy - powstało w odpowiedzi na funkcjonalne potrzeby reklamy i marketingu (Humphrey, Bradley, Somers, Gilpin, 2011): reklamowany produkt należy przedstawić potencjalnym klientom tak, aby różnice kulturowe nie wpływały na jego ocenę. Jest to więc adaptacja, która - według opisu wyznawców tej metody - zachowuje treść przekazu, zamiar i styl jego oryginalnego autora, a także obrazowanie, emocje i ton ${ }^{12}$. O różnicach między transcreation i translation najwięcej mówią używane synonimicznie określenia creative translation (przekład twórczy), free style translation (przekład w wolnym stylu) i marketing translation (przekład na potrzeby marketingu). Warunkiem skutecznego transcreation jest zatem to, co ponad pół wieku temu Eugene Nida zdefiniował jako ekwiwalencję funkcjonalną (dynamiczną),

\footnotetext{
${ }^{11} \mathrm{~W}$ recenzji porównawczego studium polskiej, czeskiej i hiszpańskiej frazeologii i paremiografii Maksymilian Drozdowicz używa terminu „przetwarzanie” (2014). Autorzy mówią także o „tłumaczeniu kreatywnym”; „sztuka transkreacji” jest definiowana - w kontekście przekładu specjalistycznego dla celów marketingowych - jako „przetworzenie materiałów oryginalnych w takiej formie, aby ich odbiór przez klienta był dokładnie taki sam, jak odbiór tekstów źródłowych przez pierwotnych adresatów" (Transkreacja czy zwykłe tłumaczenie, http://www.skrivanek.pl/pl/aktualnosci/artykuly-eksperckie/transkreacja-czy-zwykle-tlumaczenie.aspx, 2.11.2016.

${ }^{12}$ Cf. np. http://www.londontranslations.co.uk/faq/basics/ transcreation/. 19.07.2016.
} 
czyli skierowaną na wywołanie u odbiorcy reakcji analogicznej do tej, którą lektura oryginału wywołuje u oryginalnego odbiorcy. Według opisów badaczy transcreation zaleca się stosować wtedy, gdy tekst (lub, częściej, przekaz multimedialny) - ma ,zadziałać” w kulturze docelowej, czyli - jak powiedzieliśmy w odniesieniu do haiku - być interaktywny. Ogólnie rzecz biorąc, chodzi o szczególny typ tłumaczenia, które powstaje w wyniku przekładania kultury na kulturę ${ }^{13}$. Wykonać transcreation znaczy więc tyle, ile najpierw dokonać przekładu, a potem ,prze-tworzenia” translatu w taki sposób, aby w kulturze docelowej funkcjonował tak, jak oryginał w swoim pierwotnym kontekście kulturowym. W próbach zastosowania „transkreacji” do przekładu literackiego autorzy mogą się niebezpiecznie zbliżyć do zdyskredytowanej we współczesnym przekładoznawstwie metody udomowienia ${ }^{14}$. Jest to jednak problem wychodzący poza ramy niniejszego eseju.

Przykładem prze-tworzenia byłoby haiku formalnie analogiczne do oryginału, lecz przywołujące określone elementy polskiej kultury. Jako przykład można przytoczyć nagrodzony w pierwszej edycji konkursu „Wakai haiku - przestrzenie pejzaży" wiersz Marcina Bedlickiego:

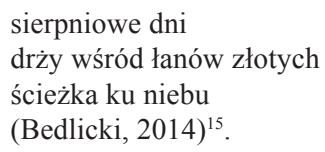

Poza niewielkimi odstępstwami od tradycyjnego podziału 5-7-5 haiku Bedlickiego spełnia wszystkie trzy omawiane powyżej warunki: jest zwięzły, zawiera „słowo pory roku”, składnia pierwszego i drugiego wersu tworzy cezurę między dwoma obrazami opartymi na polskich realiach, a dwuznaczność rzeczownika „niebo” przynosi moment epifanii. Jest więc ekwiwalentny zarówno formalnie, jak i funkcjonalnie. Czy zatem można

\footnotetext{
${ }^{13}$ Termin transcreation pojawia się także w kontekście przekładu literatur postkolonialnych - np. Vieira, 1999.

${ }^{14} \mathrm{Cf}$. np. wypowiedź tłumacza: ,Some of the phrases, images and metaphors would just not make sense in English, or would lose their original impact if translated literally, so there I had to resort to «transcreation»". In such cases, my emphasis was on the essence of the message, rather than on the literal meaning." (Nangia, 2013, 194-195). Na temat wzajemnych relacji między ,transkreacją” i udomowieniem cf. np. Wojda, 2013.

${ }^{15} \mathrm{http}$ //haikupokonkursowe.blogspot.com/2014/06/i-edycji-konkursu-wakai-haiku. html. 19.07.2016.
} 
uznać ten wiersz za produkt procesu definiowanego jako transcreation? A tłumaczenie „haiku o żabie” pióra Miłosza za „transcreation à rebours”, czyli za przekład oddający treść kosztem formy i funkcji? W szerszym zakresie są to pytania o granice przekładu i sztuk pokrewnych - adaptacji i inspiracji. Wciąż pozostające bez jednoznacznej odpowiedzi.

\section{Literatura}

Balcerzan, E. (2013). Literackość. Toruń: Wydawnictwo Naukowe Uniwersytetu im. Mikołaja Kopernika.

Bedlicki, M. (2014). [sierpniowe dni]. Z konkursu Wakai Haiku 2014. http://haikupokonkursowe.blogspot.com/. 19.07.2016.

Drozdowicz, M. (2014). Recenzja ksiązki Piotra Sawickiego i Jitki Smičekovej pt. Srovnávací frazeologie a paremiografie. Vybrané studie ze slovanských a románských jazyků / Frazeologia i paremiografia porównawcza. Wybrane studia z zakresu języków stowiańskich i romańskich. Ostrava 2010. „Academic Journal of Modern Philology", vol. 3, s. 163-168.

Gurga, L. (2003). Haiku - The Poetry of the Seasons. W: L. Gurga. Haiku: A Poet's Guide. Illinois: Modern Haiku Press, s. 1-3. http://bliskohaiq.blogspot.com/2013/07/ definicja-haiku.html. 19.07.2016.

Henderson, H. (1958). An Introduction to Haiku, an Anthology of Poems and Poets from Basho to Shiki. New York: Doubleday.

Hiraga, M. (1999). Blending and an Interpretation of Haiku: A Cognitive Approach. „Poetics Today”, vol. 20, nr 3, s. 461-481.

Hiraga, M. (2003). How metaphor and iconicity are entwined in poetry: a case in Ha$i k u$. W: From sign to signing. Red. W.G. Muller, O. Fischer. Amsterdam-Philadelphia: John Benjamins.

Humphrey, L., Bradley, J., Somers, A., Gilpin, G. (2011). The Little Book of Transcreation. London: Mother Tongue Ltd.

Izutsu, T. (2001). Haiku jako wydarzenie egzystencjalne. Przeł. A.J. Nowak. „Teksty Drugie", nr 1(66), s. 191-202.

Jakobson, R. (1960). Poetyka w świetle językoznawstwa. Przeł. K. Pomorska. Wrocław: Ossolineum.

Jarniewicz, J. (2015). Literary Translation. W: Ways to Translation. Red. Ł. Bogucki, S. Goźdź-Roszkowski, P. Stalmaszczyk. Łódź: Wydawnictwo Uniwersytetu Łódzkiego, s. 227-248.

Kowalska, T. (2002). Japońska poezja haiku. „Gazeta Uniwersytecka UŚ”, wydanie specjalne, maj. gazeta.us.edu.pl. 2.11.2016.

Kwiatkowska, A. (1999). A Cognitive Linguist Reads Haiku Poetry. W: Cognitive Perspectives on Language. Red. B. Lewandowska-Tomaszczyk. Frankfurt am Main: Peter Lang, s. 187-197. 
Langacker, R.W. (2005). Obserwacje i rozważania na temat zjawiska subiektyfikacji. Przeł. M. Majewska. Kraków: Universitas.

Langacker, R.W. (2009). Gramatyka kognitywna. Wprowadzenie. Przeł. E. Tabakowska, M. Buchta, H. Kardela, W. Kubiński, P. Łozowski et al. Kraków: Universitas.

Michałowski, P. (1999). Haiku. W: Miniatura poetycka, Szczecin: Wydawnictwo Uniwersytetu Szczecińskiego.

Miller, P. (red.) (2016). Modern Haiku. „An Independent Journal of Haiku and Haiku Studies", vol. 47.

Miłosz, C. (1992). Haiku. Kraków: Wydawnictwo M.

Mitsui, R. (2005). O stawie i żabie. „Polonia Japonica”. http://www.polonia-jp.jp/index.php/ literaturajp /item/ 641-o-stawie-i-żabie. 15.12.2015.

Nangia, S. (2013). What makes pierre fréha's french sahib a novel of globalization?: reflections of a translator. „Folia linguistica et litteraria”, nr 7, s. 189-196.

Śniecikowska, B. (2009). Obrazowość jako wyznacznik haiku - na przykładzie polskich kontynuacji i imitacji gatunku. W: Między obrazem a tekstem. Red. A. Kwiatkowska, J. Jarniewicz. Łódź: Wydawnictwo Uniwersytetu Łódzkiego, s. 131-147.

Śniecikowska, B. (2012). Figure/ground sensory segregation in Japanese and nonOriental haiku. W: Texts and Minds. Papers in Cognitive Poetics and Rhetoric. Red. A. Kwiatkowska. Frankfurt am Main: Peter Lang, s. 139-154.

Śniecikowska, B. (2014). Poezja uważności - Czesław Milosz i haiku. „Zagadnienia Rodzajów Literackich", nr LVII, z. 1, s. 9-26.

Śniecikowska, B. (2015). Oryginały czy imitacje? Wokół „,najprawdziwszych” polskich haiku. „Pamiętnik Literacki”, nr 2, s. 139-176.

Vieira, E.R.P. (1999). Liberating Calibans. Readings of Antropofagia and Haroldo de Campos' Poetics of Transcreation. W: Post-Colonial Translation. Theory and Practice. Red. S. Bassnett, H. Trivedi. London-New York: Routledge, s. 95-113.

Wojda, D. (2013). Przyrzadzanie wizerunku Murzyna w antologii ,Niam niam” Edwarda Kozikowskiego i Emila Zegadłowicza. „Przestrzenie Teorii”, z. 19, s. 77-94.

Żuławska-Umeda, A. (red.) (2006). Haiku. Bielsko-Biała: ELAY.

\section{Źródła internetowe}

Haiku. https://pl.wikipedia.org./wiki/Haiku. 19.07.2016.

Haiku Topics, Theory and Keywords. https://haikutopics.blogspot.com/2006/06/kireji. html. 15.12.2015.

https://www.wykop.pl/wpis/22381687/stara-sadzawka-zabaskok-plusk-to-jest-slnnywiers/. 21.07.2016.

London Translation. www.londontranslation.co.uk/faq/basics/transcreation/. 19.07.2016.

Polski Portal Literacki. http://www.poezja.org/wiersz,11,19353.html. 15.12.2015.

Strona internetowa agencji tłumaczeniowej Skrivanek. http://www.skrivanek.pl/ pl/aktualnosci/artykuly-eksperckie/transkreacja-czy-zwykle-tlumaczenie.aspx. 15.12.2015. 